Научная рецензия на академическое издание:

Китайско-русский визуальный словарь с транскрипцией /

сост. Н. Н. Воропаев; под ред. Ма Тяньюй. М.: АСТ, 2019. 319 с.

Изотов А. И.

\title{
Chinese-Russian Visual Dictionary with Transcription / N. N. Voropaev (comp.); Ma Tianyu (ed.). Moscow: AST Publ., 2019. 319 p.: Opinion Paper
}

Izotov A. I.

Рецензируемое издание - одно из серии визуальных словарей (в которую входят также словари англорусский, немецко-русский, французско-русский, итальянско-русский, испанско-русский, японско-русский, корейско-русский), издаваемых АСТ. С заявленным объемом в четыре с половиной тысяч слов и словосочетаний он относится к так называемым малым словарям и ориентирован, как нам представляется, на пользователя, владеющего (или пытающегося овладеть) китайским языком на уровне В1 по общеевропейской классификации или же, что более привычно в отечественном педагогическом дискурсе, на уровне английского Intermediate и желающего освежить свой словарный запас перед поездкой в Китай, перед встречей с китайскими коллегами или же перед каким-либо еще важным мероприятием, требующим мобилизации лингвистических знаний и компетенций в данной области.

Материал словаря охватывает 14 тем, распадающихся, в свою очередь, на подтемы, которые вполне покрывают, на наш взгляд, основные коммуникативные потребности находящегося в стране туриста, решившего обойтись без переводчика и рассчитывающего на собственные силы. Речь идет о следующих темах и подтемах:

тема дом 居家 с подтемами дом 房屋, квартира 公寓, вход 入口, гостиная 起居室, спальня 卧室，постельное бельё床上用品, столовая 餐厅, посуда и столовые приборы 餐具, кухня 征房, кухонная техника 厨房电器, кухонная утварь 厨具, детская комната 儿童室, уход за ребёнком 儿童呵护, сон 睡眠, еда 饮食, ванная комната 浴室, мастерская 工具房, виды работы 工作方法, инструменты 工具, свёрла для дрели 钻头, сад 花园, виды садов 花园种类, садовый инвентарь 花园器具; тема люди тело 身体, лицо 脸, кисть 手, ступня 脚, мышцы 肌肉, скелет 骨胳, позвоночник 脊椎, сустав 关节, семья 家 庭; тема ЗДоРОВЬЕ 健康 с подтемами болезнь 疾病, на приёме у врача 看病, травма 创伤, нетрадиционная медицина 替代医学; тема РАБОТА 工作 с подтемами профессия 专业, офис 办公室, рабочее место 工作 岗位, офисное оборудование 办公设备, компьютер 电脑; тема ОБУЧЕНИЕ 学习 с подтемами школа 学校, фигуры 平面图形, тела 立体, линии 线, инструменты 学习用具, специализированные школы专科学校, высшее образование 高等院校, библиотека 图书馆; тема ПОКУПКИ 购物 с подтемами торговый центр 购物 中心, универмаг 百货商店, мужская одежда 男装, женская одежда 女装, обувь 鞋, головные уборы 帽子, аксессуары 配饰, сумки 包, цветочный магазин 花店, супермаркет 超市, сладости 糖果, тара 包装; тема ПИЩА 食品 с подтемами мясо 肉类, сорта мяса 切块, птица 禽类, рыба и морепродукты 鱼类和海鲜, овощи 蔬菜, фрукты 水果, ягоды и бахчевые культуры 瓜果类, орехи 坚果, сухофрукты 干果, злаки и бобовые 谷物和豆类, злаки 谷物, крупы 谷粒, рис 大米, семена 种子, бобовые и стручковые 豆类, макаронные изделия 通心粉, травы 药叶菜, пряности 香料, молочные продукты 乳制品, сыры 奶酪, молоко 奶品, пирожные и десерты 甜品, праздничные торты 节日蛋糕, хлеб и мука 面包和面粉, выпекание хлеба 焙面包, яйца 蛋类, деликатесы 美味; тема ОБЩЕСТВЕННОЕ ПИТАНИЕ 餐饮业 с подтемами кафе 咖啡馆, кофе 咖啡, чай 茶, соки 果汁, молочные коктейли 奶昔, еда 食物, бар 酒吧, алкогольные напитки 酒类, лёгкая закуска 零食， ресторан 餐厅， сервировка стола 餐具摆饭，блюда 菜品，быстрое питание 快餐， завтрак 早餐， обед/ужин 午餐/晚餐, первое блюдо 头菜, основное блюдо 主菜, способы приготовления 做法, виды гарниров 配菜种类, десерты 甜品; тема СЛУЖБЫ 公共事业 с подтемами банк 银行, финансы 金融, гостиница 酒店, 
вестибюль 前厅, номер 房间, обслуживание 服务, средства связи 通讯, почта 邮件, телефон 电话, чрезвычайные службы紧急救护服务, скорая помощь 急救, первая помощь 救护, полиция 警察, пожарная команда 消防队; тема ТРАНСПОРТ 交通工具 с подтемами дороги 道路, дорожные знаки 交通标志, заправочная станция 加油站, автомобиль 1 汽车, внешний вид 外视, типы автомобилей 车种, автомобиль 2 汽车, салон 内饰, управление 整车控制, общественный транспорт 公共交通工具, поезд 火车, типы поездов 火车 种类, самолёт 飞机, авиалайнер 客机, аэропорт 机场, салон 机舱内部, судно 船舶, другие суда 其他船舶; тема досуг 休闲 с подтемами досуг 休闲, музей 博物馆, театр 剧院, балет 芭蕾舞剧, кинотеатр 电影院, концерт 音乐会, музыкальные инструменты 乐器, туризм 观光, места посещений 观光点, активный отдых 户外活动, парк 公园, пляж 海滩; тема СПОРТ 运动 с подтемами футбол 足球, хоккей 曲棍类运动, хоккей с шайбой 冰球, хоккей на траве 曲棍球, хоккей с мячом на льду 班迪球, баскетбол篮球, действия 动作, волейбол 排球, пляжный волейбол 沙滩排球, гандбол 手球, теннис 网球, удары 打击, игры с ракеткой 拍类 运动, лёгкая атлетика 田径运动, спортивная гимнастика 竞技体操, художественная гимнастика 艺术体操, фехтование 击剑, конькобежный спорт 速滑, фигурное катание 花样滑冰, биатлон 冬季两项, стрельба 射击, кёрлинг 冰壶, водные виды спорта 水上运动, академическая гребля 划艇运动, безопасность 安全, парусный спорт 帆船运动, плавание 游泳, стили 风格, прыжки в воду 跳水, синхронное плавание 花样游泳, водное поло 水球, подводное плавание с аквалангом 水肺潜水, бокс 拳击, удары 击打, защита 保护, единоборства 格斗运动, греко-римская борьба 古典式摔跤, вольная борьба 自由式摔跤, действия 动作, конный спорт 马术运动, гольф 黄道十二宫高尔夫球, снаряжение 球具, клюшки для гольфа 高尔夫球杆, бейсбол 棒球, площадка 游乐场, действия 动作, фитнес 健身; тема ОКРУЖАЮЩАЯ СРЕДА 环境 с подтемами космос 太空, освоение космоса 太空探索, астрономия 天文学, зодиакальные созвездия 黄道十二宫星座, Земля 地球, строение Земли 地球构造, ландшафт 景观, почвы 土壤, погода 天气, город 城市, районы 区域, архитектура 建筑学, здания и сооружения 建筑和建筑结构, стили 建筑风格; тема ФЛОРА И ФАУНА 植物和动物 с подтемами животные 动物, млекопитающие 哺乳动物, птицы 鸟类, земноводные 两栖类, рыбы 鱼类, пресмыкающиеся 爬行类, беспозвоночные 无脊椎动物, растения 植物, дерево 树木, хвойные 松柏目, широколиственные 阔叶树木, цветущие растения 显花植物, травянистые растения 草本植物, грибы 蘑菇.

Сгруппированные по названным подтемам слова иллюстрируются цветными фотографиями или рисунками. Например, подтема гостиная 起居室 представлена несколькими фотографиями со стрелками и подписями (привожу только русский вариант. - А. И.): светильник, картина, часы, потолок, каминная полка, сервант, телевизор, кресло, пол, журнальный столик, ваза, камин, ковёр, диван, диванная подушка, жалюзи, штора, портьера, тюлевая занавеска, лепнина, люстра, книжная полка, торшер, настольная лампа, диван-кровать, кабинет.

Пожалуй, единственным существенно затрудняющим пользование словарем недостатком является отсутствие транскрипции у заголовочных и «подзаголовочных» слов, причем эта транскрипция отсутствует не только в оглавлении, что было бы простительно, но и на соответствующих страницах. И это при том, что у слов «внутри» подтем указывается не только основанная на путунхуа транскрипция пиньинь, но и весьма неудачная, на наш взгляд, «транскрипция» русскими буквами, ср. 电视机 diànshìjī дъиеншыдзи телевизор. Загонять слово одного языка в прокрустово ложе графем языка другого - дело изначально проигрышное, но, если уж так хочется, почему бы не воспользоваться традиционной в нашей стране системой Палладия, которая хоть и появилась задолго до пиньиня, однако основана на том же 官话 (букв. 'язык чиновников'), который англичане обозвали «мандаринским китайским» и который фактически лёг в основу путунхуа? Тогда «озвучка» приведенного сочетания иероглифов выглядела бы как дянышицзи.

Можно отметить также следы того, что словник издания с его структурой тем и подтем изначально составлялся и не на русском, и не на китайском, а на каком-то третьем языке, ср. одинаково звучащие по-русски названия первой темы (дом 居家, букв. 'жилище семьи') и первой подтемы этой же темы (дом 房屋, букв. 'жилое помещение'), а также китайский вариант подтемы здания и сооружения (建筑和建筑结构) с повтором иероглифов 建筑 'здание', так что буквально получилось «здание и строение здания». Есть и другие не очень удачные формулировки в названиях, например, подводное плавание с аквалангом вместо дайвинга, есть и повторы, см. выше.

Впрочем, всё это относится не столько к содержанию, сколько к особенностям оформления издания, которое будет, безусловно, полезным всем преподающим или изучающим китайский язык на базе русского.

\section{Информация об авторах | Author information}

RU Изотов Андрей Иванович ${ }^{1}$, д. филол. н., доц.

${ }^{1}$ Московский государственный университет имени М. В. Ломоносова; Московский педагогический государственный университет

EN Izotov Andrey Ivanovich ${ }^{1}$, Dr

${ }^{1}$ Lomonosov Moscow State University; Moscow Pedagogical State University

${ }^{1}$ a.i.izotov@mail.ru

Информация о статье | About this article 